\title{
Three-dimensional mapping and kinematic characterization of mass transport deposits along the outer Kumano Basin and Nankai accretionary wedge, southwest Japan
}

\author{
Jason Lackey ${ }^{1}$, Gregory Moore ${ }^{1 *}$ and Michael Strasser ${ }^{2}$
}

\begin{abstract}
Three-dimensional (3D) seismic data from the southern Kumano Basin of southwest Japan image a nested series of moderately sized mass transport deposits (MTDs) that slid from a slope along the seaward side of the forearc basin. The deposits are dated to be approximately 0.3 to $0.9 \mathrm{Ma}$. These MTDs are likely linked to the movement along a prominent out-of-sequence thrust (OOST) fault, regionally steeper slopes that would have existed during deposition, and shifts in sedimentation over the past $0.9 \mathrm{Ma}$. The spatial resolution provided by the 3D seismic data permits the identification of kinematic characteristics and the internal geometries of the MTDs which total over $2.8 \mathrm{~km}^{3}$ in volume and cover more than $59 \mathrm{~km}^{2}$ of the seafloor at various stratigraphic levels. Each MTD is well imaged and exhibits various kinematic indicators while most of the basal glide planes and original headwall scarps above the deposits have been partially or fully eroded by subsequent MTDs. There are at least seven individual deposits that range in volume from 0.005 to $1.16 \mathrm{~km}^{3}$, in area from 0.2 to $21.8 \mathrm{~km}^{2}$; have runouts between 0.55 and $7.9 \mathrm{~km}$, and generally translate downslope from the SE to NW. Basal, internal, and top surface kinematic indicators, such as grooves, thrust and fold systems, and pressure ridges, show that these MTDs originate from a prominent slide scar recognized in the high-resolution regional bathymetry. This, combined with a regionally shifting depocenter and faulting related to the earthquake cycle, points to regional tectonic activity as being the most likely failure trigger for these nested landslides.
\end{abstract}

Keywords: Mass transport deposit, 3D, Landslide, Nankai, Accretionary, Subduction, Kinematic

\section{Introduction}

Subaqueous landslides occur in many different environments all over the world including both active and passive margins, along the flanks of volcanic islands, and river deltas (Prior and Coleman 1978; Moore et al. 1989; Lee 2009) and can occur on a great variety of slopes (ranging from $<0.01^{\circ}$ to vertical (Prior and Coleman 1978)). These slides can be devastating to seafloor infrastructure via high-speed turbidity currents and to coastal communities in the form of tsunami (Bondevik et al. 1997; Bardet et al. 2003; Satake 2012). Characterization by their size, shape, and kinematics allows us to better

\footnotetext{
* Correspondence: gmoore@hawaii.edu

'Department of Earth Science, University of Hawai'i, 1680 East-West Rd, Honolulu, HI 96822, USA

Full list of author information is available at the end of the article
}

understand how they initiate and translate downslope to the point at which they arrest (Ward and Day 2002).

The movement of the failed mass from the source of failure to the point of arrestment can be analyzed and described using kinematic indicators present in either seismic data (Prior et al. 1984; Bøe et al. 2000; Gee et al. 2005, 2006) or outcrops (Farrell 1984; Lucente and Pini 2003; Matheus et al. 2017). In a general sense, kinematics describes the motion of bodies without the consideration of the body's mass or forces that caused its motion. Here, we follow Bull et al. (2009) in defining "kinematic indicator" as a geologic structure or feature which records information related to the type and direction of motion at the time of emplacement. This information is of great use in helping us understand the motions involved with slide initiation, evolution during translation downslope, and cessation. Additionally, because of the complex nature of 
submarine landsliding, many variably active processes are likely involved in each mass movement. This leads to a litany of potential classifications and terminology. Here, we chose to simplify the classification of deposits from various mass movements identified in the data as simply "mass transport deposits" (MTDs).

This study represents a unique opportunity to analyze several Quaternary MTDs via a 3D seismic reflection survey in the Kumano Basin along the Nankai accretionary prism. Some of these MTDs were previously identified by Moore and Strasser (2016); however, no kinematic analysis was performed nor was a reconstruction of the original slope attempted. Because they are fully imaged in the 3D survey, a complete analysis of kinematic indicators and morphology is possible. A kinematic analysis of these MTDs should provide greater insight into the depositional environment in which sliding occurred and determine a possible explanation as to the origin of a prominent seafloor scar (Lackey et al. 2018).

\section{Regional setting and study area}

The Kumano Basin is within the Nankai Trough subduction zone where the Philippine Sea Plate is presently subducting under the Amur Plate at a rate of 4 to $6 \mathrm{~cm} \mathrm{yr}^{-1}$ (Seno 1989). The NW oblique subduction has led to the creation of an accretionary prism spanning roughly $700 \mathrm{~km}$, with the overall oblique slip being apportioned along a large right-lateral strike-slip fault, known as the Median Tectonic Line, landward of the prism (Fitch 1972; Taira 2001). The accreted sediment is primarily terrigenous detritus from Honshu Arc, Japan, and hemipelagic deposits on the Philippine Sea Plate (Underwood and Moore 2012). The upper part of the hemipelagic section from the Philippine Sea Plate is accreted while the lower part is subducted beyond the inner prism (e.g., Kinoshita et al. 2009; Kimura et al. 2011; Strasser et al. 2011; Strasser et al. 2012; Underwood and Moore 2012; Moore et al. 2014). The inner prism is overlain by the Kumano Forearc Basin which has formed over approximately the past 1.95 to $2.0 \mathrm{Ma}$ behind the outer ridge that is believed to be the result of the movement along the megasplay fault (Gulick et al. 2010; Moore et al. 2015). The seismic recurrence interval of roughly 100 to 200 years for large earthquakes has been well established for Nankai (Ando 1975). The rapid growth of the accretionary prism is an important factor for large, repeated earthquakes in this subduction zone setting (Ruff and Kanamori 1980).

The present study area is within the Kumano Forearc Basin just landward of the outer ridge of the accretionary prism (Fig. 1). The 3D seismic data used for this study covers roughly $275 \mathrm{~km}^{2}$ (Moore and Strasser 2016) and is located entirely within the transition zone of the accretionary prism between 35 and $50 \mathrm{~km}$ from the deformation front (Kimura et al. 2007). Seafloor depths vary from $1700 \mathrm{~m}$ seaward of the study area to $2100 \mathrm{~m}$ landward. Notable characteristics include numerous faults in both the 3D data and bathymetry, temporally sequential landslide scars, and an absence of surficial landslide deposits (e.g., Strasser et al. 2009; Moore et al. 2013; Lackey et al. 2018).

\section{Methods/Experimental}

To identify MTDs and kinematic indicators, we interpreted several prominent horizons throughout our 3D seismic survey, including basal shear surfaces (BSS), tops of MTDs, and various depositional layers. Amplitude and coherency data are then displayed on these horizons to highlight geomorphic structures and kinematic indicators with the goal of reconstructing the various MTDs to their original positions. To validate the conclusions drawn from the data, we compare our results to other subaqueous landslide kinematic studies (e.g., Frey Martinez et al. 2005, 2006; Gee et al. 2005, 2006; Bull et al. 2009; Moore and Strasser 2016) that utilize 3D seismic reflection data.

\section{D volume}

The full 3D survey covers roughly $12 \mathrm{~km} \times 56 \mathrm{~km}$ extending from the Kumano Basin seaward to the frontal thrust in the dip direction (Fig. 1). The acquisition occurred aboard the M/V Nordic Explorer during April to May 2006 under contract by Petroleum Geo-Services (PGS). Two sound source arrays (totaling $51 \mathrm{~L}$ or 3090 in. $^{3}$ ) were utilized and fired alternately at $37.5 \mathrm{~m}$ shot intervals. The survey used four $4500 \mathrm{~m}$ long receiver cables spaced $150 \mathrm{~m}$ apart with 360 receiver groups at $12.5 \mathrm{~m}$ spacing. This geometry yielded eight source-receiver common midpoint (CMP) lines per sail line at $37.5 \mathrm{~m}$ spacing (Moore et al. 2009). The interval between the lines and cross lines of the resulting data set is $18.75 \mathrm{~m}$ and $12.5 \mathrm{~m}$, respectively. The vertical resolution is $\sim 5-7 \mathrm{~m}$ near the seafloor, degrading to 10-20 m at depths near $1400 \mathrm{~m}$ below seafloor (mbsf; Moore et al. 2009). Standard pre-processing to reduce noise preceded pre-stack depth migration (PSDM) and produced a clear seismic image in depth (Moore et al. 2009). For the seaward part of our area, we were able to use a reprocessed version of the $3 \mathrm{D}$ data set that produced much higher-resolution images of the sedimentary section (Shiraishi et al. 2018).

\section{Bathymetry data}

High-resolution bathymetry data analyzed for surficial MTDs has been acquired during R/V Sonne Expedition 251 in October 2016 (Strasser et al. 2017). The R/V Sonne is equipped with an EM 122 KONGSBERG multibeam echosounder (MBES) operated at $12 \mathrm{kHz}$. The transducers have a nominal opening of $0.5^{\circ}$ in 


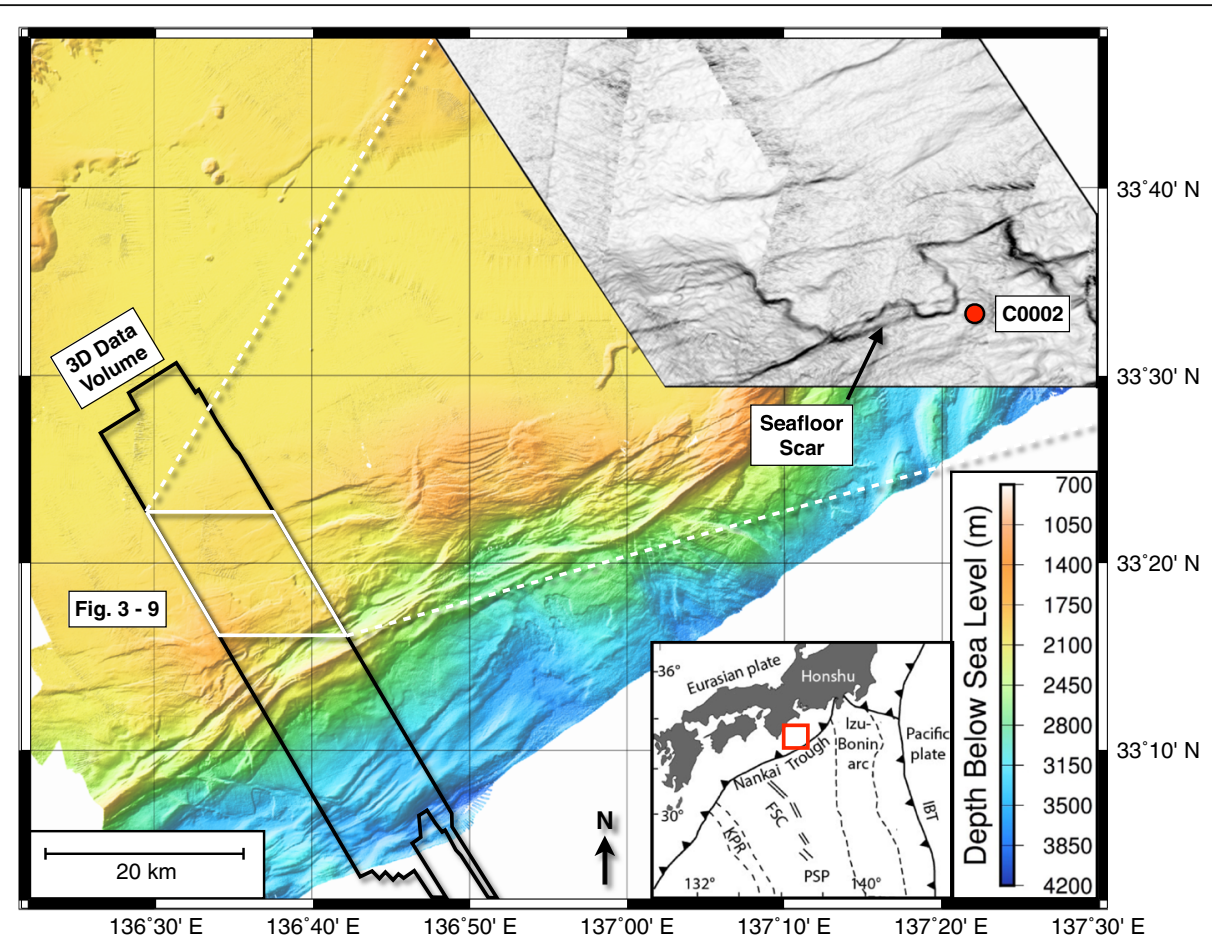

Fig. 1 Study area. High-resolution bathymetry of the Kumano Basin acquired by R/V Sonne during Cruise SO251 in 2016 (Strasser et al. 2017 ). The trapezoidal inset shows a slope gradient map of a prominent seafloor scar from Lackey et al. (2018) and the location of IODP drill site C0002

along-track direction and $1^{\circ}$ in across-track direction. The MBES recorded 433 individual beams across track within a swath of $120^{\circ}$. Actual sound velocity profiles were recorded with the ships CTD and inserted as the basis for optimized performance. Data were processed with software MB-System (Caress and Chayes 1996).

\section{Core data}

Coring of the Kumano Basin sediments was accomplished on Integrated Ocean Drilling Program (IODP) Expeditions 315 (Kinoshita et al. 2009) and 338 (Strasser et al. 2014) (Fig. 1). The cored interval consists of hemipelagic mud and numerous thin interbeds of normally graded silt, sandy silt, and sand with local layers of volcanic ash (Underwood and Moore 2012). For a more detailed analysis of the core data, see Underwood and Moore (2012). These data demonstrate that nearly all the basin fills accumulated within the last 1.6 Ma.

\section{MTD recognition and kinematic indicators}

MTDs are typically identified by their internal chaotic reflection character or semitransparent to transparent seismic character. Once a MTD is identified, other seismic indicators (e.g., hummocky reflections, truncations of stratigraphic layers, folds, and thrusts) are used to characterize the remainder of the MTD. For the purposes of this study, we subdivide each MTD into three domains based on which kinematic indicators are most likely to occur in a typical "tripartite" MTD anatomy (Martinsen 1994; Lastras et al. 2002): the headwall, translational, and toe domains (Fig. 2). While there is almost always an overlap between these domains, it is important to have a clear delineation between them to properly study the kinematic indicators in the data.

\section{Headwall domain}

The two prominent kinematic indicators in this region are headwall scarps and extensional ridges and blocks that represent the extensional, upslope portion of the MTD (Bull et al. 2009). Crown cracks may also develop upslope of the primary headwall scarp (Fig. 2).

\section{Translational domain}

The translational domain is defined as the main body of failed material that has moved downslope. It is subdivided into four sections based on their differing physical parameters: lateral margins, basal shear surface, internal MTD body, and top MTD surface (Martinsen 1994; Frey Martinez et al. 2005; Bull et al. 2009).

\section{Toe domain}

Characterized by an overall convex-downslope morphology, the toe domain represents the region of downslope termination of the main MTD body and is characterized by thrust and fold systems and pressure ridges (Prior et al. 1984; Frey Martinez et al. 2005). 


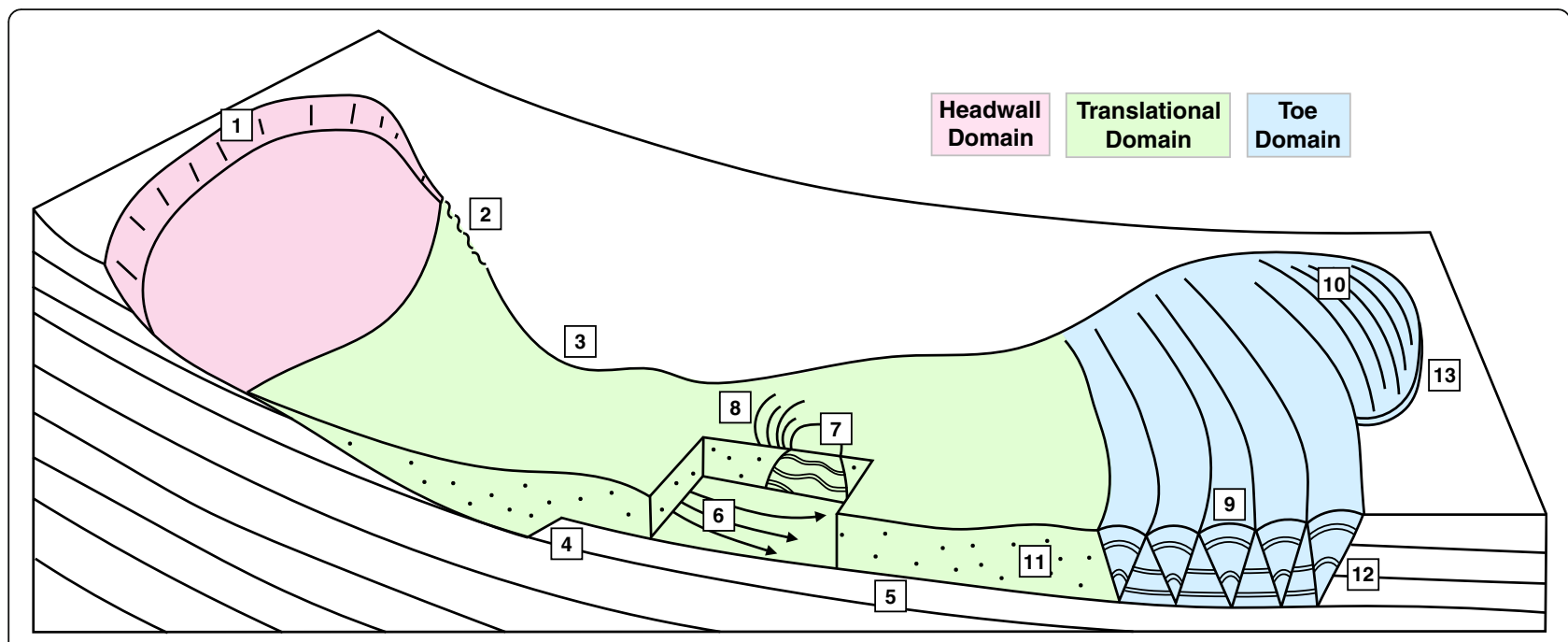

Fig. 2 Key geometric and geologic criteria for kinematic indicator recognition. 1-headwall scarp. The direction of initial movement roughly perpendicular to the headwall propagation. 2-en-echelon sigmoidal segments. Strike-slip affected MTD material differentiates lateral margin from headwall scarp. 3-lateral margins. Delimits strike-parallel extent of MTD and constrains gross general transport direction. 4-ramp. Location(s) where the BSS jumps to a higher stratigraphic level. 5-flat. Location(s) where the BSS is parallel with local stratigraphy. 6-grooves. Implies debris flow processes with a translation parallel to their trend. 7-translated block. Often align long-axis downslope. 8-secondary flow fabric. Translation direction indicated by the trend of flow parallel banding. 9-pop-up blocks. Typically hundreds of meters high, translation perpendicular to the alignment of ridges. 10 - pressure ridges. Typically tens of meters high, translation perpendicular to the strike of thrust faults. 11—MTD matrix. 12-frontally confined toe. 13 - frontally emergent toe. BSS—basal shear surface. MTD—mass transport deposit. Modified after Bull et al. (2009)

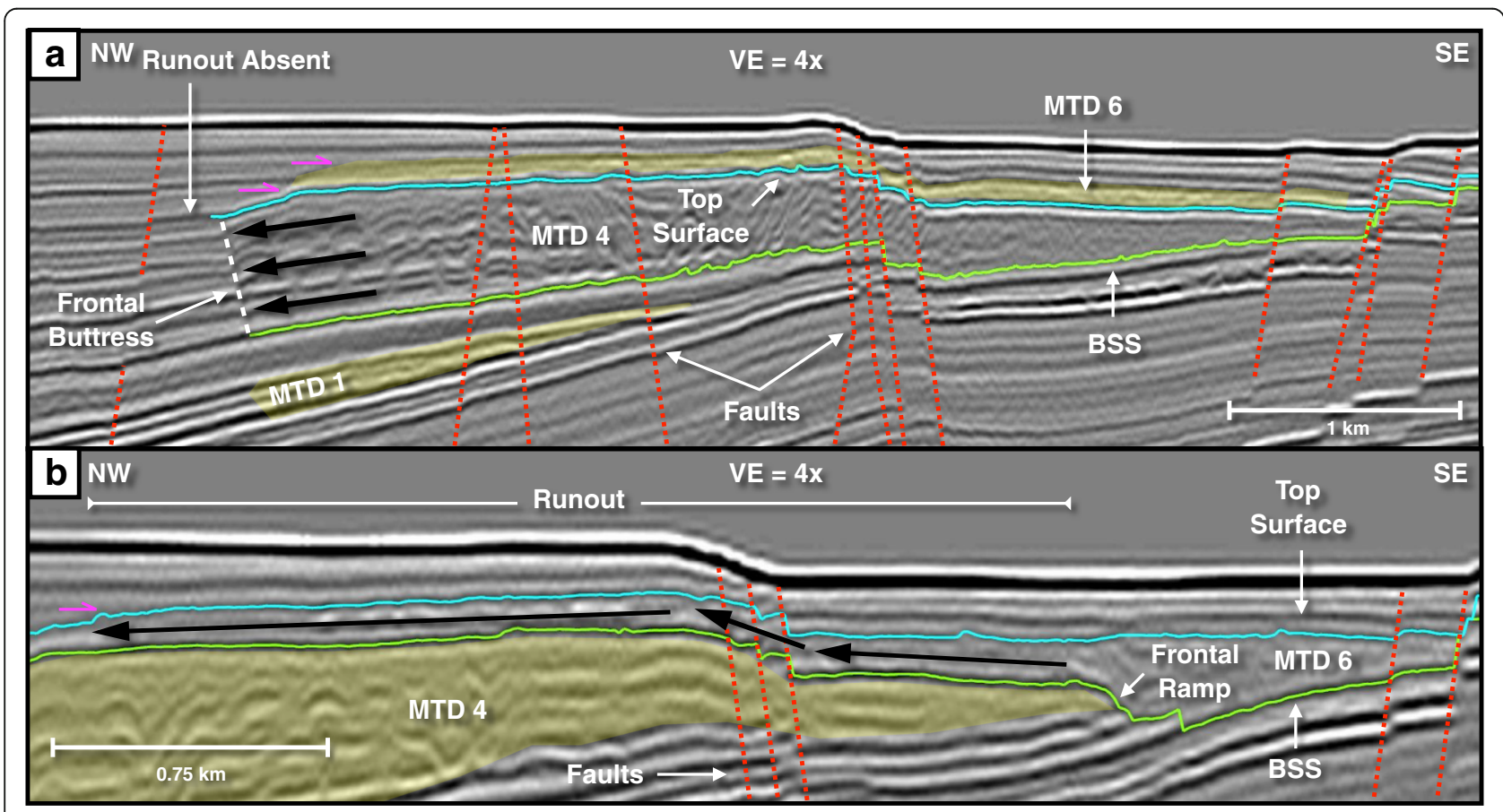

Fig. 3 Frontally confined versus frontally emergent MTDs. Black arrows indicate primary translation direction. Purple arrows indicate onlapping relationships. BSS — basal shear surface. a Frontally confined landslide. The arbitrary seismic line across MTD 4 (see Fig. 6 for location). Note how the landslide mass is buttressed against undisturbed strata. b Frontally emergent landslide. Seismic Inline 2352 across MTD 6 (see Fig. 7 for location). Note the runout of the landslide mass beyond the frontal ramp 
Frontally confined MTDs are those where the toe domain exhibits impressive thrust and fold systems that are buttressed against stratigraphically equivalent undisturbed strata downslope while frontally emergent MTDs are able to ramp up from the original basal shear surface and translate freely across the seafloor (Frey Martinez et al. 2006) (Fig. 3).

\section{Results}

We identified seven individual MTDs in the 3D data that range in volume from 0.005 to $1.16 \mathrm{~km}^{3}$, in area from 0.2 to $21.8 \mathrm{~km}^{2}$, have runouts between 0.55 and $7.88 \mathrm{~km}$, and generally translate downslope from the SE to NW. The MTDs total over $2.8 \mathrm{~km}^{3}$ in volume and cover more than $59 \mathrm{~km}^{2}$ of the seafloor at various stratigraphic levels. The MTDs have been designated as MTD 1 through MTD 7 based upon their relative temporal occurrences with MTD 1 being the oldest. Measurements for all MTDs are summarized in Table 1. Additionally, three surficial MTDs were identified in high-resolution bathymetry that were not fully resolvable in the 3D seismic data.

\section{Headwall domain}

Kinematic indicators for the headwall domain were difficult to identify in the data. While headwall scarps were partially or fully identified in most of the MTDs, extensional blocks were completely absent.

\section{Headwall scarps}

Although evidence for headwall scarps exists for most of the landslides, most of them could not be fully identified (Figs. 4, 5, 6, 7). All headwall scarps are located under a prominent complex landslide scar identified by Lackey et al. (2018) except for MTD 2. Because of the overlapping nature of their locations, we believe that the difficulty in identifying full headwall scarps is due to erosion by subsequent mass failures at higher stratigraphic levels. This is especially true for MTDs 1, 3, and 6 as there are no discernable headwall scarps in the data leading us to conclude that they have been fully eroded (Figs. 4b, 5b, 7b). Additionally, only a portion of the headwall scarp was identifiable for MTD 4 (Fig. 6b).

Table 1 Physical MTD parameters and identified kinematic indicators

\begin{tabular}{|c|c|c|c|c|c|c|c|c|c|}
\hline MTD & $\begin{array}{l}\text { Stratigraphic } \\
\text { sequence and age }\end{array}$ & $\begin{array}{l}\text { Volume } \\
\left(\mathrm{km}^{3}\right)\end{array}$ & $\begin{array}{l}\text { Area } \\
\left(\mathrm{km}^{2}\right)\end{array}$ & $\begin{array}{l}\text { Average } \\
\text { thickness (m) }\end{array}$ & $\begin{array}{l}\text { Runout } \\
(\mathrm{km})\end{array}$ & $\begin{array}{l}\text { Translation } \\
\text { direction }\end{array}$ & $\begin{array}{l}\text { Headwall } \\
\text { domain }\end{array}$ & Translational domain & $\begin{array}{l}\text { Toe domain } \\
\text { (confined/emergent) }\end{array}$ \\
\hline 1 & $\begin{array}{l}\text { Kumano } 4 \\
0.9 \text { Ma to } 0.3-0.44 \mathrm{Ma}\end{array}$ & 0.999 & 21.8 & 45.8 & 7.884 & $\mathrm{~S} \rightarrow \mathrm{N}$ & None & $\begin{array}{l}\text { LM: scarps, en-echelon } \\
\text { sigmoidal segments } \\
\text { BSS: flats, grooves } \\
\text { IMB: translated block } \\
\text { TMS: second-order fabric }\end{array}$ & Confined: thrusts \\
\hline 2 & $\begin{array}{l}\text { Kumano } 4 \\
0.9 \mathrm{Ma} \text { to } 0.3-0.44 \mathrm{Ma}\end{array}$ & 0.03 & 1.5 & 20 & 1.729 & $\mathrm{SE} \rightarrow \mathrm{NW}$ & Headwall & $\begin{array}{l}\text { LM: scarps } \\
\text { BSS: flats } \\
\text { IMB: none } \\
\text { TMS: none }\end{array}$ & Emergent: pressure ridges \\
\hline 3 & $\begin{array}{l}\text { Kumano } 3 \\
0.3-0.44 \text { Ma to Present }\end{array}$ & $0.358^{*}$ & $7.73^{*}$ & 46.3 & 3.238 & $\mathrm{SE} \rightarrow \mathrm{NW}$ & None & $\begin{array}{l}\text { LM: scarps, en-echelon } \\
\text { sigmoidal segments } \\
\text { BSS: ramps, flats } \\
\text { IMB: translated blocks } \\
\text { TMS: none }\end{array}$ & Confined: thrusts \\
\hline 4 & $\begin{array}{l}\text { Kumano } 3 \\
0.3-0.44 \text { Ma to Present }\end{array}$ & 1.155 & 14.15 & 81.62 & 5.741 & $\mathrm{SE} \rightarrow \mathrm{NW}$ & Headwall & $\begin{array}{l}\text { LM: scarps, en-echelon } \\
\text { sigmoidal segments } \\
\text { BSS: ramps, flats } \\
\text { IMB: translated Blocks } \\
\text { TMS: none }\end{array}$ & Mostly confined: thrusts \\
\hline 5 & $\begin{array}{l}\text { Kumano } 3-2 \\
0.3-0.44 \text { Ma to Present }\end{array}$ & 0.005 & 0.2 & 25 & 0.552 & $S \rightarrow N$ & Headwall & $\begin{array}{l}\text { LM: scarps } \\
\text { BSS: ramps, flats } \\
\text { IMB: none } \\
\text { TMS: none }\end{array}$ & $\begin{array}{l}\text { Mostly confined: thrusts, } \\
\text { pressure ridges }\end{array}$ \\
\hline 6 & $\begin{array}{l}\text { Kumano } 2-1 \\
0.3-0.44 \mathrm{Ma} \text { to Present }\end{array}$ & 0.297 & 13.1 & 22.7 & 4.136 & $S \rightarrow N$ & None & $\begin{array}{l}\text { LM: scarps } \\
\text { BSS: ramps, flats } \\
\text { IMB: none } \\
\text { TMS: none }\end{array}$ & Emergent: none \\
\hline 7 & $\begin{array}{l}\text { Kumano } 2-1 \\
0.3-0.44 \mathrm{Ma} \text { to Present }\end{array}$ & 0.031 & 1.2 & 25.8 & 1.508 & $\mathrm{SW} \rightarrow \mathrm{NE}$ & Headwall & $\begin{array}{l}\text { LM: scarps } \\
\text { BSS: flats } \\
\text { IMB: none } \\
\text { TMS: none }\end{array}$ & Emergent: pressure ridges \\
\hline
\end{tabular}



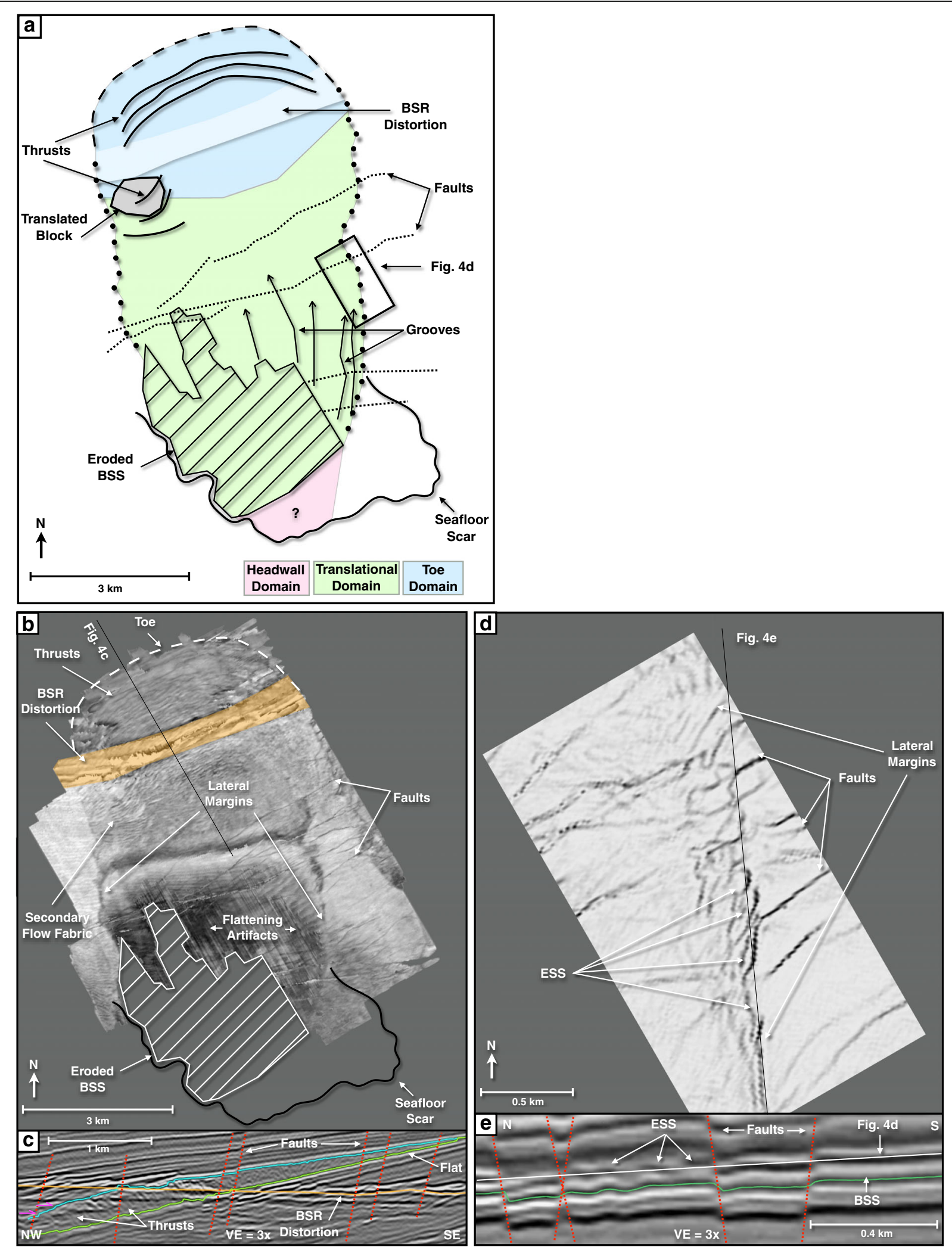

Fig. 4 (See legend on next page.) 
(See figure on previous page.)

Fig. 4 MTD 1 interpretations. The primary direction of translation is S $\rightarrow$ N. BSR—bottom-simulating reflector; BSS—basal shear surface; ESS-enechelon sigmoidal segments. a Schematic depiction of the domains and main kinematic features within MTD 1. b Seismic amplitude map of structurally flattened BSS. c Inline seismic cross section 2480 transecting the translational and toe domains. Note that BSR reflection crosscuts the MTDs and disrupts the stratal continuity. Purple arrows indicate onlapping relationships. $\mathbf{d}$ Structurally flattened coherency slice showing a lateral margin of MTD 1 (location shown in a). e Arbitrary seismic cross section along the lateral margin of MTD 1. Location of the line is shown in $\mathbf{d}$

\section{Extensional ridges and blocks}

No extensional blocks were identified for any of the MTDs. The most likely reasons for their absence are that the headwall regions were fully evacuated of material, subsequent erosion by stratigraphically higher failures (as with the headwall scarps), or insufficient resolution of the data. All headwall regions appear to be void of any failure material, indicating that any extensional blocks that may have formed continued to translate downslope and become blocks in the translational domain or fully disintegrated into the MTD matrix. Because we believe many of the headwall scarps were eroded by subsequent mass failures, it is also likely that any extensional blocks that may have remained immediately after failure were also eroded.

\section{Translational domain}

The majority of the kinematic indicators found in the data are located in the translational domain. Lateral margins, ramps, and flats are well represented in the data. We believe this domain to be so well represented due to its containing the bulk of the failed material for each MTD and because almost all the translational domains were well preserved and imaged when compared to the headwall and toe domains.

\section{Lateral margins}

All MTDs have lateral margin scarps that are visible in the data. Some of the margins are easily interpreted for the entire MTD (Figs. 4b, 6b) while others have either been eroded by subsequent mass failure (Fig. 5b) or are not fully resolvable in the data (Fig. 7b). En-echelon sigmoidal segments are imaged in MTDs 1, 3, and 4 (Figs. 4d, 5d, 6d). Only portions of the lateral margins exhibit these segments, and in each instance, the segments are only 50 to $100 \mathrm{~m}$ in length.

There was added difficulty in the accurate identification of lateral margins as the strata are offset by numerous faults throughout the 3D volume (Moore et al. 2013). To overcome this, seismic amplitude and coherency are displayed onto interpreted horizons that are then structurally flattened (Fig. 8). When viewing an internal amplitude slice using MTD 1's structurally flattened basal shear surface, a linear break in amplitude appears upslope of the main body of failed material (Fig. 4b). The orientation of this linear feature is consistent with the MTD's other kinematic indicators such as grooves found in the basal shear surface. These data support an interpretation that this linear feature is most likely a lateral margin.

\section{Basal shear surface}

The basal shear surfaces for all MTDs are mapped to their fullest extent possible. Many of the surfaces are incomplete due to uncertainties in the data from ubiquitous faulting throughout the data set or due to erosion from subsequent mass failures. Grooves appear in the basal shear surface of only MTD 1 and are made visible only by displaying amplitude data onto a structurally flattened basal shear surface. The fact that they do not show in seismic cross section suggests that these features are near the limit of the data's resolution. This could also explain their absence in the remainder of the MTDs.

Flats are present in all the MTDs as all their basal shear surfaces are primarily parallel to the local stratigraphy. Ramps, however, are only located in MTDs 3, 4, 5, and 6 (Figs. 5c, 6c, and 7c) and all trend perpendicular to their MTD's primary flow direction. The absence of parallel trending ramps, by definition, means that slots are also absent from the data (Bull et al. 2009). Additionally, there are no instances of the basal shear surface ramping down and cutting into the underlying stratigraphy, only ramping up to higher stratigraphic levels.

None of the MTD basal shear surfaces exhibit signs of striations. As these features are caused by outrunner blocks (of which there was none identified), their absence is not a surprise. It is possible, however, that these features exist, especially for the MTDs that are partially or fully emergent and are simply unresolvable in the data.

\section{Internal MTD body}

Translated blocks were identified in MTDs 1, 3, and 4 (Figs. 4a, 5a, 6a). Their absence in the remaining MTDs likely has a connection with their average thickness (Table 1). Because each stratigraphic horizon is roughly equal to the vertical resolution of the data, a block would need to be at least $20-28 \mathrm{~m}$ ( $\times 4$ the vertical resolution) in height to be easily distinguishable from the surrounding strata. The average thickness of MTDs 2, 5, 6, and 7 is 20-26 m. Therefore, any blocks within the failed mass of these MTDs could have been easily overlooked as belonging to the local stratigraphy. This may also explain the absence of remnant and outrunner blocks as neither of these block types were identified for any of the MTDs. 


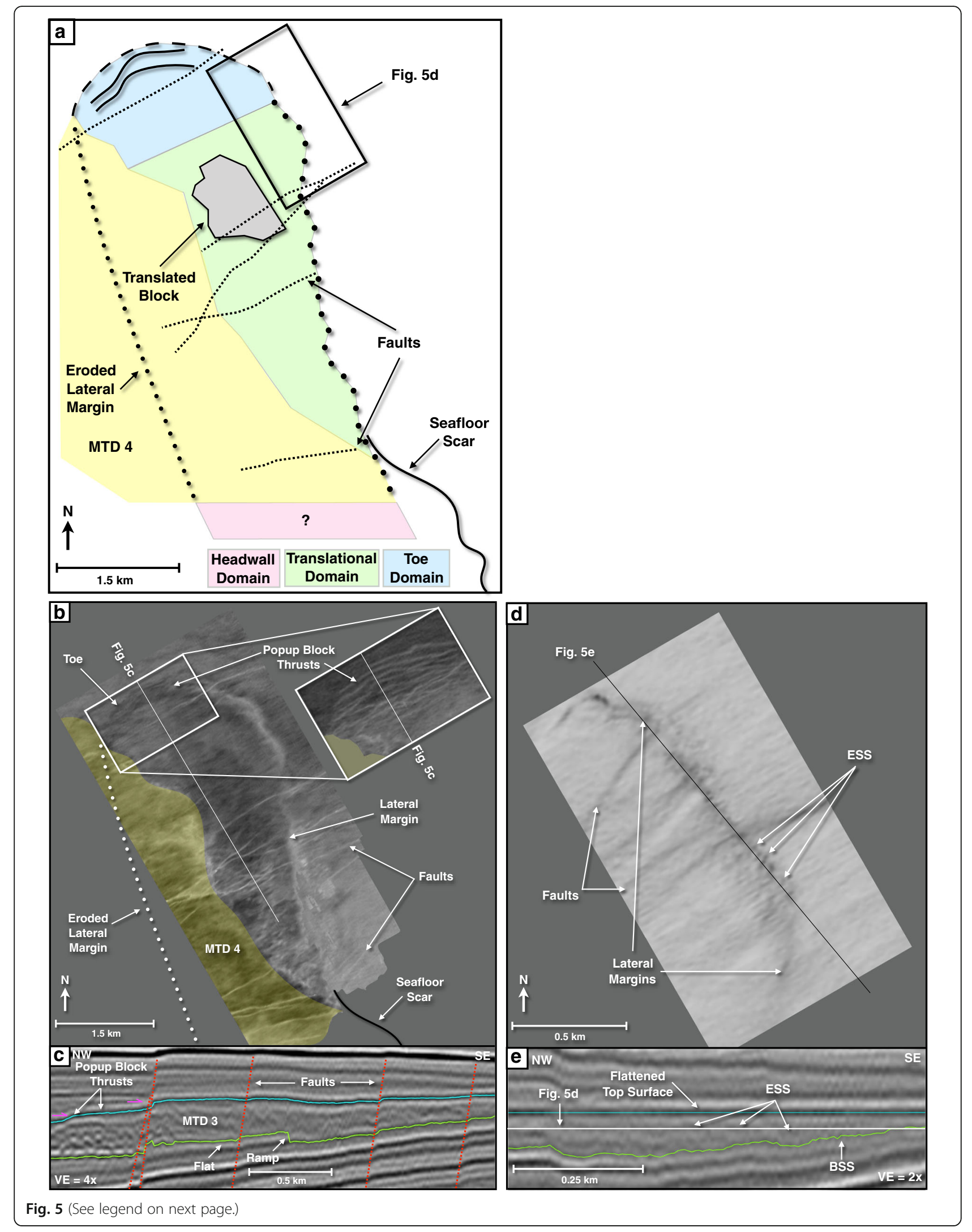


(See figure on previous page.)

Fig. 5 MTD 3 interpretations. The primary direction of translation is SE $\rightarrow$ NW. BSS—basal shear surface; ESS —en-echelon sigmoidal segments. a Schematic depiction of the domains and main kinematic features within MTD 3. The question mark indicates an undefined headwall domain due to erosion. The large yellow area indicates the location of MTD 4. b Seismic amplitude map of the structurally flattened top surface of MTD 3 (blue line in c). Inset is a structurally flattened portion of the BSS showing thrusts in the toe domain. $\mathbf{c}$ Inline seismic cross section 2492 transecting the translational and toe domains (location shown in $\mathbf{b}$ ). $\mathbf{d}$ Structurally flattened coherency slice showing a lateral margin of MTD 3 (location shown in a). Note the en-echelon sigmoidal segments. e Arbitrary seismic cross section along the lateral margin of MTD 3 (location shown in d)

Outside of the toe domain's thrust and fold systems, folds were not identified in any of the MTDs. Given the large degrees of deformation and the runouts for these deposits, it is unlikely that folding did not take place during emplacement. Therefore, the most likely explanation for their absence is that they are below the resolution of the data as folding has been identified in sub-seismic scale failures in outcrop (Farrell 1984; Lucente and Pini 2003; Matheus et al. 2017).

\section{Top MTD surface}

Only MTD 1 exhibited a kinematic indicator from the top surface. A second-order flow fabric was identified above and around a translated block (Fig. 4b). The likely explanation for this fabric centers around the MTD's translated block. It likely became buttressed against the lateral margin of the MTD, causing the failed material to be forced around the flow obstruction which leads to thrusting within the failed mass and a secondary fabric in the top surface (Fig. 4b).

There were no instances of longitudinal shear zones in any of the MTDs. The majority of these types of kinematic indicators have been found on much larger MTDs in other places around the world (Masson et al. 1993; Gee et al. 2005; Gafeira et al. 2007). Therefore, we believe that the MTDs in this study are either too small to exhibit such differences in flow speed within the failed mass or that this indicator is simply not resolved in the data.

\section{Toe domain}

The toe domain is identified on all MTDs. However, although the toe of MTD 6 was identifiable, it lacked any kinematic indicators within the domain (Fig. 7). The most likely explanation for this absence is that the toe domain is not thick enough to either contain or resolve any of the indicators. Also unique to MTD 6 were a hummocky terrain and turbidite located beyond the toe domain. Their existence is likely due to the amount of material scoured from MTD 4 during the emplacement of MTD 6 (eroded BSS; Fig. 6).

The toe domain of MTD 1 also proved difficult to map. A strong bottom-simulating reflector (BSR) caused by gas hydrate accumulations is imaged 200-400 mbsf across the entire area of interest within the 3D seismic volume (Miyakawa et al. 2014). This led to inaccuracies in mapping the toe domain of MTD 1, causing kinematic indicators that would otherwise be visible to be either partially or fully obscured (Fig. 4).

\section{Thrust and fold systems}

Thrust and fold systems were identified in MTDs 1, 3, 4, and 5 (Figs. 3c, 5c, and $6 \mathrm{c}$ ). The confined nature and thickness of these MTDs are the primary causes of the thrust and fold systems. Of note, MTDs 3 and 4 both display pop-up block systems while MTDs 1 and 5 exhibit simple thrust systems. It is possible, however, that MTD 1 also contains pop-up blocks as its thickness is similar to that of MTD 3. The BSR that obscures MTD 1 's toe domain may simply prevent the pop-up blocks from being resolvable (Fig. 3c).

\section{Pressure ridges}

MTDs 2 and 7 both exhibit pressure ridges in their toe domains. Because thrusts are typically found in conjunction with pressure ridges in outcrop (Masson et al. 1993; Gee et al. 2005; Gafeira et al. 2007), it is likely that some sort of thrust system exists in both MTDs and are simply too small to resolve in the $3 \mathrm{D}$ data.

\section{Surficial MTDs}

The seafloor scar identified by Lackey et al. (2018) appears to contain at least three surficial MTDs that could not be fully identified in the 3D data (Fig. 9b). These MTDs are clearly visible as seafloor features in high-resolution bathymetry (Strasser et al. 2017). Their absence from the 3D data is likely due to their relatively small scale and their recent occurrence. Because they are recent failures, they have yet to be buried and will, therefore, be poorly imaged in 3D seismic data. While kinematic indicators from these surficial MTDs cannot be identified in the 3D data, they are still important in understanding the evolution of the seafloor with respect to this study.

\section{Discussion}

The MTDs identified in this study exhibit numerous kinematic indicators that enable us to determine the spatial and relative temporal origin of each failure. We have reconstructed each of the failures to their original positions and, using the local stratigraphy, temporally sequenced each failure in the most probable order (Fig. 10). Each of the MTDs (with the notable exception of MTD 2) appears to originate stratigraphically below the 


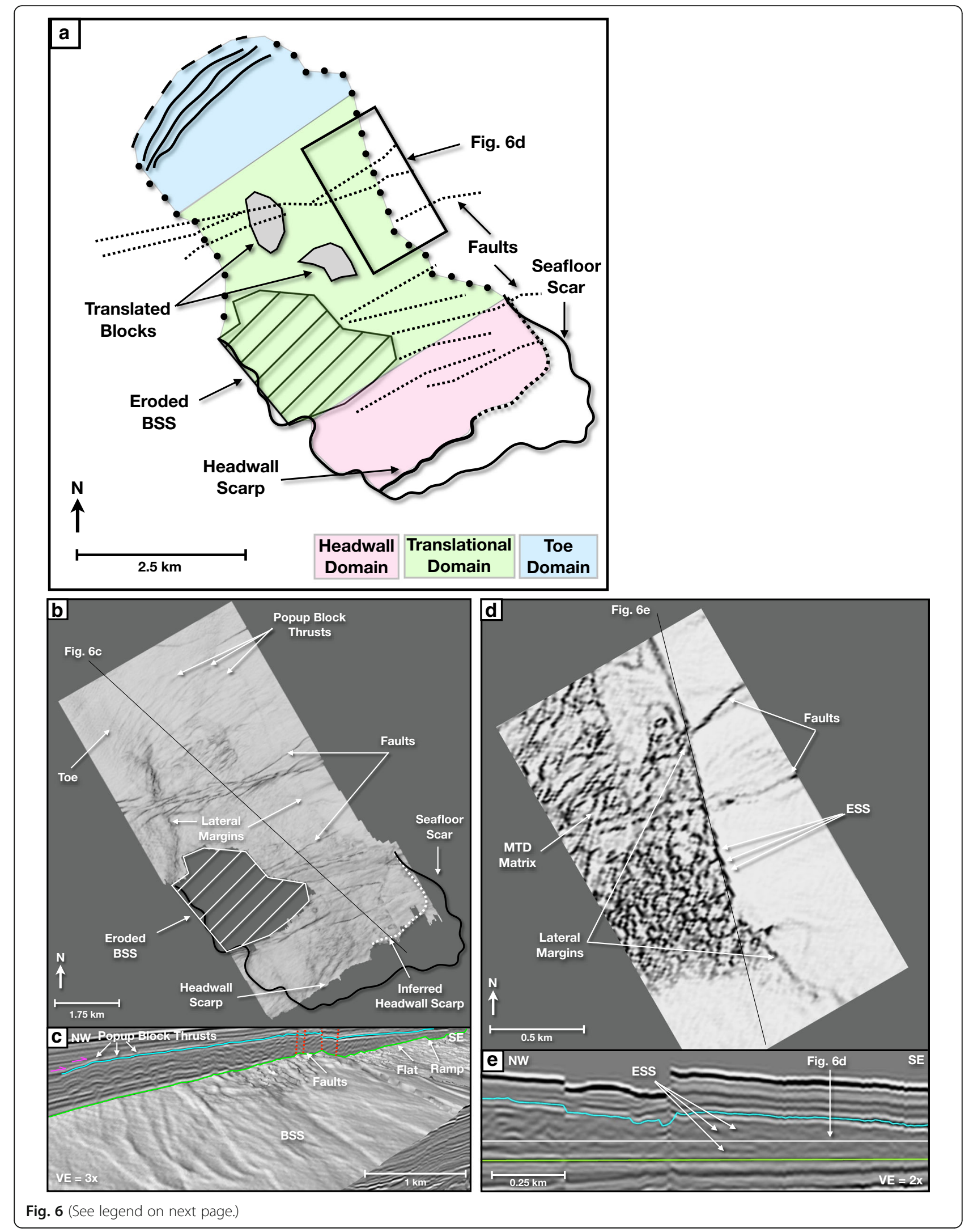


(See figure on previous page.)

Fig. 6 MTD 4 interpretations. The primary direction of translation is SE $\rightarrow$ NW. BSS—basal shear surface; ESS—en-echelon sigmoidal segments. a Schematic depiction of the domains and main kinematic features within MTD 4. b Coherency map of structurally flattened BSS. c Arbitrary seismic cross section transecting MTD 4 from the headwall domain to the toe domain (location shown in $\mathbf{b}$ ). $\mathbf{d}$ Structurally flattened coherency slice showing a lateral margin of MTD 4 (location is shown in a). Note the en-echelon sigmoidal segments. e Arbitrary seismic cross section along the lateral margin of MTD 4 (location of the line shown in $\mathbf{d}$ )

seafloor scar identified by Lackey et al. (2018). These, combined with the three surficial deposits that could not be identified in the 3D data, fully explain the geometry of the scar.

We interpret the scar's location to be associated with the local depositional and tectonic environment over the past $0.9 \mathrm{Ma}$. All MTDs are located within the stratigraphic sequences Kumano 4-Kumano 1 identified by Gulick et al. (2010). Kumano 4 is the oldest of these sequences, with deposition beginning $\sim 0.9 \mathrm{Ma}$. During this time, motion along a prominent out of sequence thrust (OOST) was reactivated, potentially by the continued subduction of a seamount on the Philippine Sea Plate (Kimura et al. 2011; Moore et al. 2013), causing the outer forearc to continue tilting landward as it had during the deposition of the Kumano 8 sequence $\sim 1.2 \mathrm{Ma}$ (Moore et al. 2015). A series of normal faults that are spatially correlated with a SW uplift penetrates through the Kumano 5 and Kumano 4 sequences but does not penetrate the Kumano 4 sequence boundary (K4) (Fig. 11b). This indicates that the uplift took place rapidly and ceased by $\sim 0.3-0.44 \mathrm{Ma}$ (Moore et al. 2015). This rapid uplift and resultant slope steepening coupled with seismic loading could explain the occurrence of MTDs 1 and 2 since they are fully contained within the Kumano 4 sequence and are spatially correlated. Of note, there is a lack of MTDs in stratigraphic sequences older than the Kumano 4 sequence. We believe this to be because of the hiatus in tilting (a key preconditioning factor) between the deposition of Kumano sequences 5-7 (Moore et al. 2015).

MTDs 3-7 and the surficial MTDs occur within or above the Kumano 3 sequence, making them $<0.3-0.44 \mathrm{Ma}$ in age and indicating potentially different causal mechanisms. Kumano sequences 3-1 thicken in the landward direction from $<50 \mathrm{~m}$ in the seaward region to $>600 \mathrm{~m}$ toward the basin center (Moore et al. 2015). Isopach maps created by Moore et al. (2015) show a general widening and NW shift of the basin depocenter over time (Fig. 12). This shift has led to a decrease in deposition around the seafloor scar since 0.3-0.44 Ma and is the most likely explanation for the general decrease in the size of the MTDs over time. We infer this because, as sediment deposition decreases with time, there will be less material available to slide. Additionally, the edge of the forearc basin ceased tilting by the deposition of $\mathrm{K} 4$ as evidenced by the onlapping relationships of the Kumano 4-1 sequences (Gulick et al. 2010). Because neither local steepening nor high rates of sedimentation occurred during the emplacement of MTDs 3-7 or the surficial MTDs, another causal mechanism likely exists.

The Nankai region has a well-documented and regular history of small and great earthquake activity (Ando 1975; Kimura et al. 2011). Great earthquakes along the margin are documented as far back as $648 \mathrm{AD}$ with a recurrence interval of 100 to 200 years (Ando 1975). If a splay fault, such as the Nankai megasplay, ruptures co-seismically, amplification of seismic ground shaking can occur within the hanging wall (Abrahamson and Somerville 1996). This has been suggested for Nankai and other splay fault systems (e.g., Plafker 1972; Tanioka and Satake 2001; Baba et al. 2006), thereby representing a plausible causal link between seismic loading and slope failure. However, as noted by Moore and Strasser (2016), the recurrence interval for landsliding in the Kumano Basin appears to be about 0.05 to $0.1 \mathrm{Ma}$, which is much less frequent than the recurrence interval for Nankai's great earthquakes. Kremer et al. (2017) suggested that this difference could be due to slopes being preconditioned to fail because of climate forcing during interglacial periods. However, they were unable to resolve the relative contributions of tectonic versus climate preconditioning factors, and Urlaub et al. (2013) showed that the ages of landslides on passive margins can be described by a temporally random Poisson distribution and therefore do not show a positive correlation between the frequency of major slope failures on passive margins and sea level changes during the past $0.18 \mathrm{Ma}$. Another possibility is that the extent of updip rupture propagation along the megasplay fault is not always sufficient to cause slope failure. Ikari et al. (2011) found that the triggering of slope failure for a statically stable slope by a $M_{w}$ 6-8 earthquake requires the megasplay to rupture within $12 \mathrm{~km}$ of the slope.

Shear strengthening (Locat et al. 2002; Lee et al. 2004) could also be an explanation as to why failure is less frequent than the great earthquake recurrence interval, especially for $M_{w}$ 6-8 earthquakes (Ikari et al. 2011). An instantaneous increase in pore pressure is induced on saturated, fine-grained sediment during an earthquake. This temporarily weakens the sediment. However, if it is not weakened to the point of failure, the pore pressure diffuses over time permitting the sediment to become over-consolidated. Therefore, an earthquake that does not cause slope failure could lead to an increase in the 

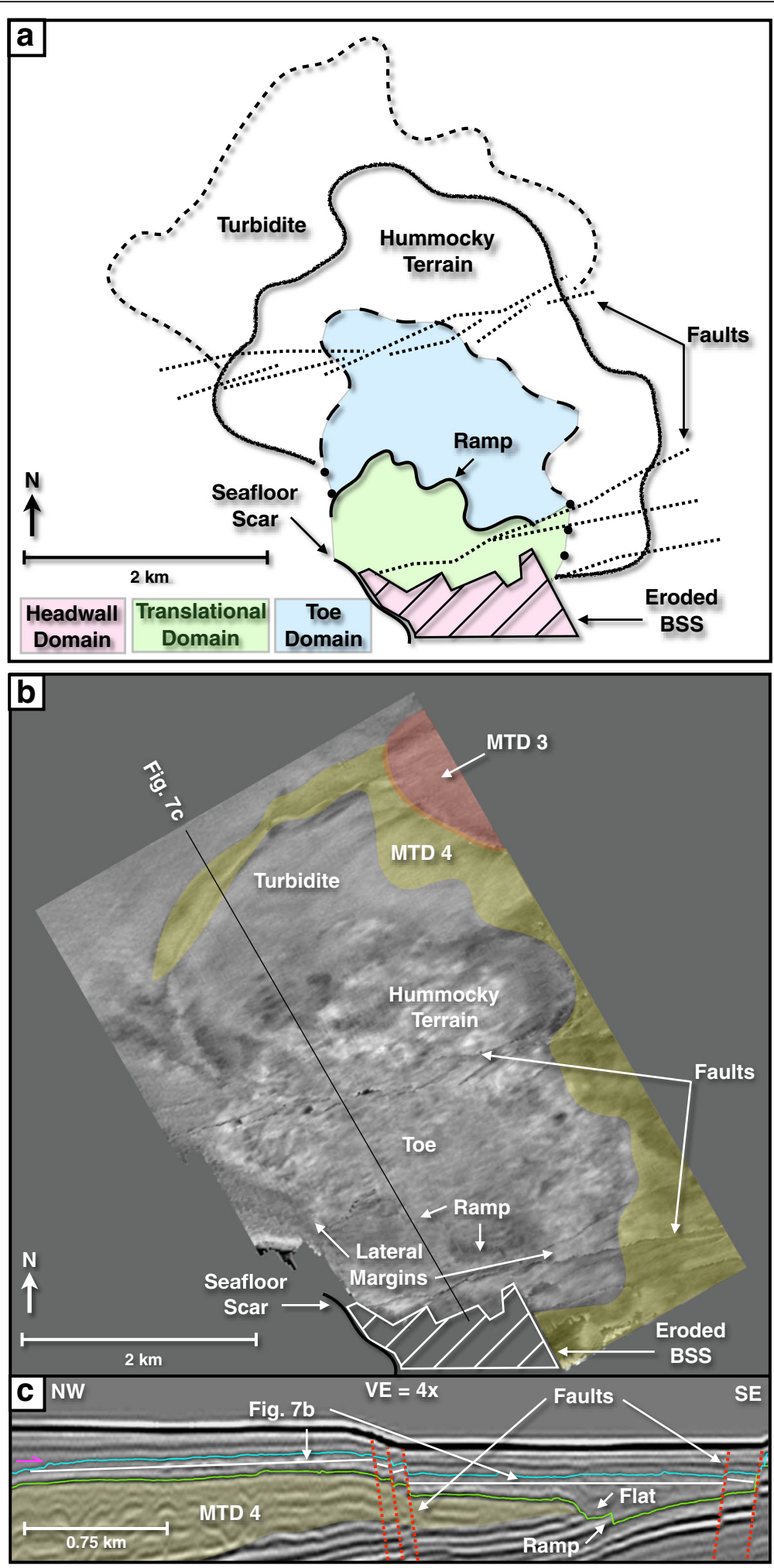

Fig. 7 MTD 6 interpretations. The primary direction of translation is S $\rightarrow$ N. BSS - basal shear surface. a Schematic depiction of the domains and main kinematic features within MTD 6. Distribution of hummocky terrain and a turbidite are also identified. $\mathbf{b}$ Structurally flattened amplitude slice through MTD 6. Inline seismic cross section 2352 transecting the translational and toe domains of the MTD. Location shown in $\mathbf{b}$. $\mathbf{c}$ Inline seismic cross section 2352 transecting all three domains (location shown in Fig 7b). Note the hummocky reflections in the NW half of the cross section 


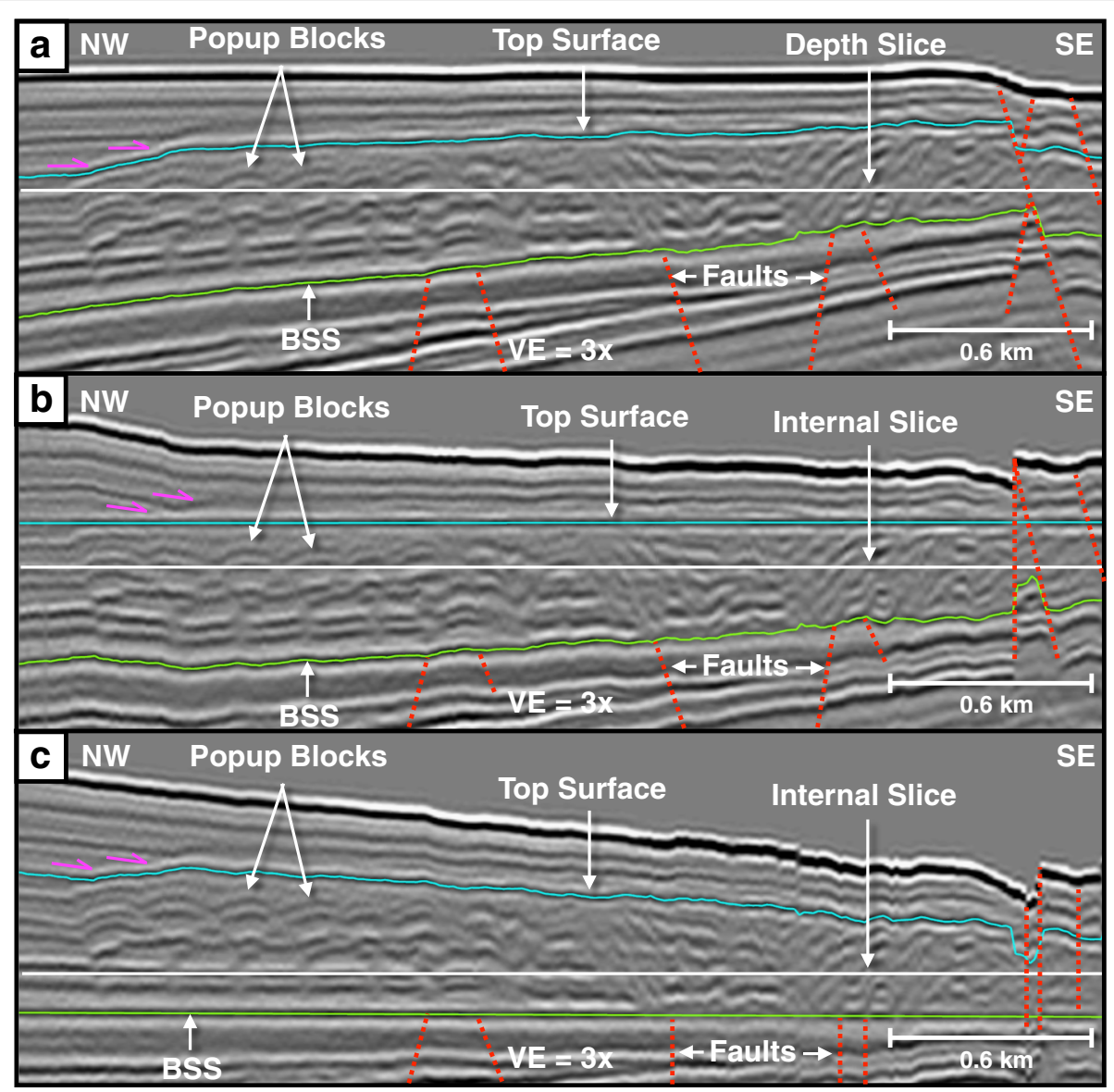

Fig. 8 Structural flattening of interpreted horizons, see Fig. 11a for arbitrary line location. The primary direction of translation is SE $\rightarrow$ NW. BSS - basal shear surface. Purple arrows indicate onlapping relationships. a Arbitrary seismic line of MTD 4 toe domain. Note how the depth slice (white line) intersects the pop-up blocks at various stratigraphic levels. b Structurally flattened top surface. Note how the flattened image permits an internal slice (white line) to cross the top surface of each pop-up block. c Structurally flattened BSS. Note how the flattened image permits an internal slice (white line) to cross the pop-up blocks at the same stratigraphic level near the BSS

slope's shear strength that increases its resistance to future failures (DeVore and Sawyer 2016). A resistance to future failure implies that either an even larger earthquake would be required to initiate sliding or another causal mechanism is ultimately at work such as the activation of a fault.

Three normal fault populations exist in the study area. The youngest population (phase 3; Sacks et al. (2013); Moore et al. (2013)) tends to cut the upper strata of the forearc basin and manifest as scarps on the seafloor which have been identified in this study. Sacks et al. (2013) proposed a mechanism, via the earthquake cycle, by which the differing orientation of these fault populations and the arcuate geometry of the faults associated with our study originated. During the late inter-seismic period, faults perpendicular to the trench can undergo slip, while faults oriented parallel to the trench undergo slip during post-seismic extension. Additionally, Moore et al. (2013) showed that these faults are likely short-lived rather than regional phenomenon as they lack growth structures. These two conclusions support the idea that these faults occur in conjunction with the earthquake cycle.

A landslide does not occur during each seismic event, possibly in part to the effects of shear strengthening. However, landsliding can occur because of the change in the regional stress regime during the post-seismic phase of the earthquake cycle leading to favorable normal faulting conditions that strike parallel to the trench axis. Because all of the MTDs in this study (except for MTDs 1 and 2, likely caused by local over steepening a seismic loading) appear to have headwall scarps either on or near a trench parallel fault within the youngest of Sacks et al.'s (2013) populations, we propose that the primary final trigger mechanism for these nested MTDs is failure as a result of faulting during the post-seismic relaxation of the accretionary prism or massive megathrust earthquakes along the megasplay fault. 

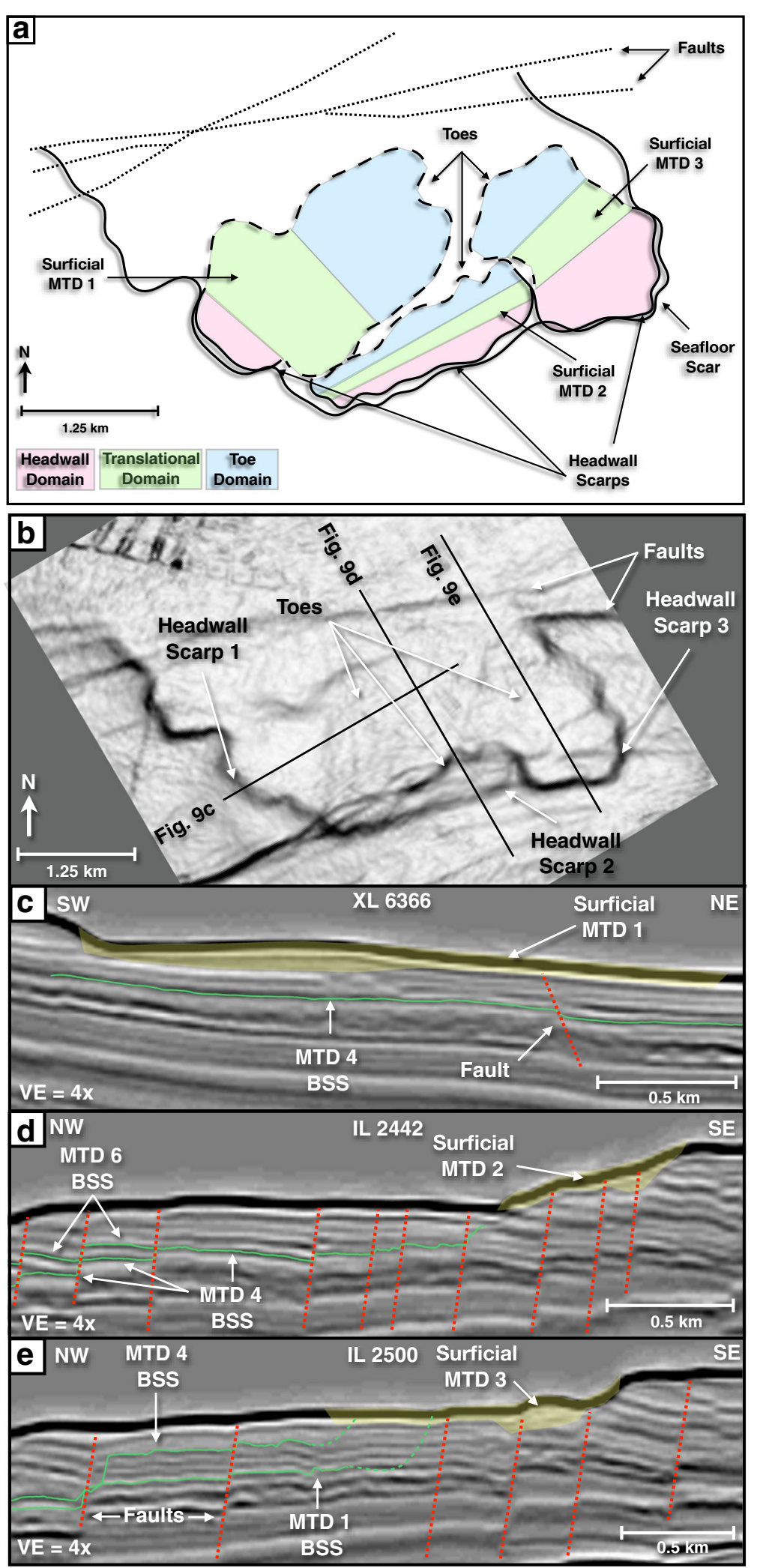

Fig. 9 Surficial MTDs. a Schematic depiction of three surficial MTDs. $\mathbf{b}$ Bathymetric image of surficial landslide scar showing the location of three surficial landslides. c-e Seismic cross sections across the surficial MTDs in the 3D seismic data. Green lines are BSSs of older landslides. Red dotted lines are normal faults 

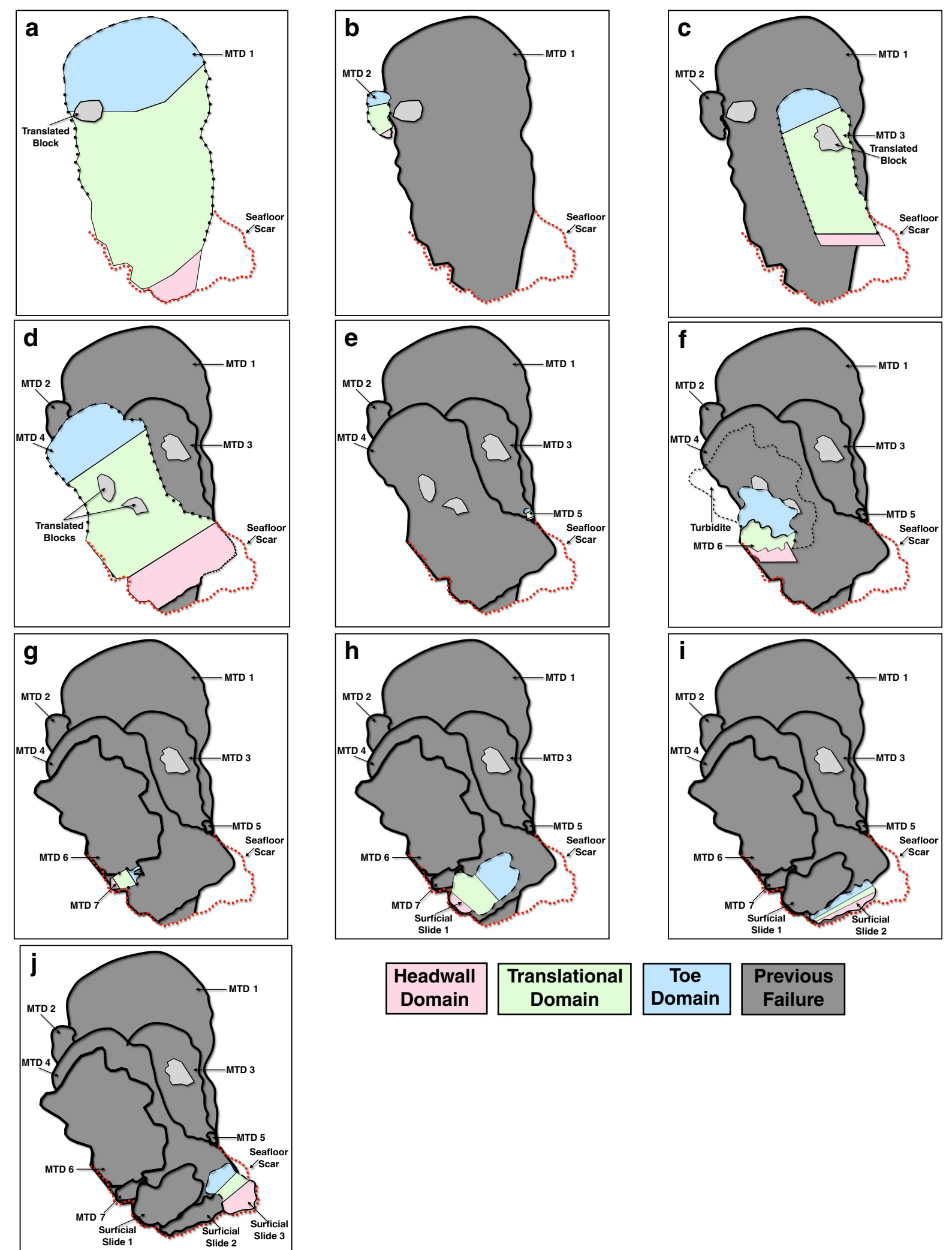

Fig. 10 (See legend on next page.) 
(See figure on previous page.)

Fig. 10 Schematic reconstruction of the seafloor scar. Based on the kinematic indicators and geometry of each MTD. a MTD 1 occurs and begins the process toward creating the seafloor scar. b MTD 2 occurs because of rapid uplift to the SW (Fig. 11a). c MTD 3 emplaces on top of MTD 1 after a $0.46 \mathrm{Ma}$ hiatus in landsliding. d MTD 4 occurs soon after MTD 3 and erodes the W margin and at least 1/3 of MTD 3 as well as a portion of the BSS of MTD 1. e MTD 5 is possibly a result of lateral margin failure of either MTD 3 or 4. $\mathbf{f}$ MTD 6 erodes a portion of MTD 4's BSS and deposits a turbidite on its top surface. $\mathbf{g}$ MTD 7 erodes a portion of MTD 6's basal shear surface and creates the W boundary of the seafloor scar. $\mathbf{h}-\mathbf{j}$ Three surficial landslides finish shaping the current seafloor scar

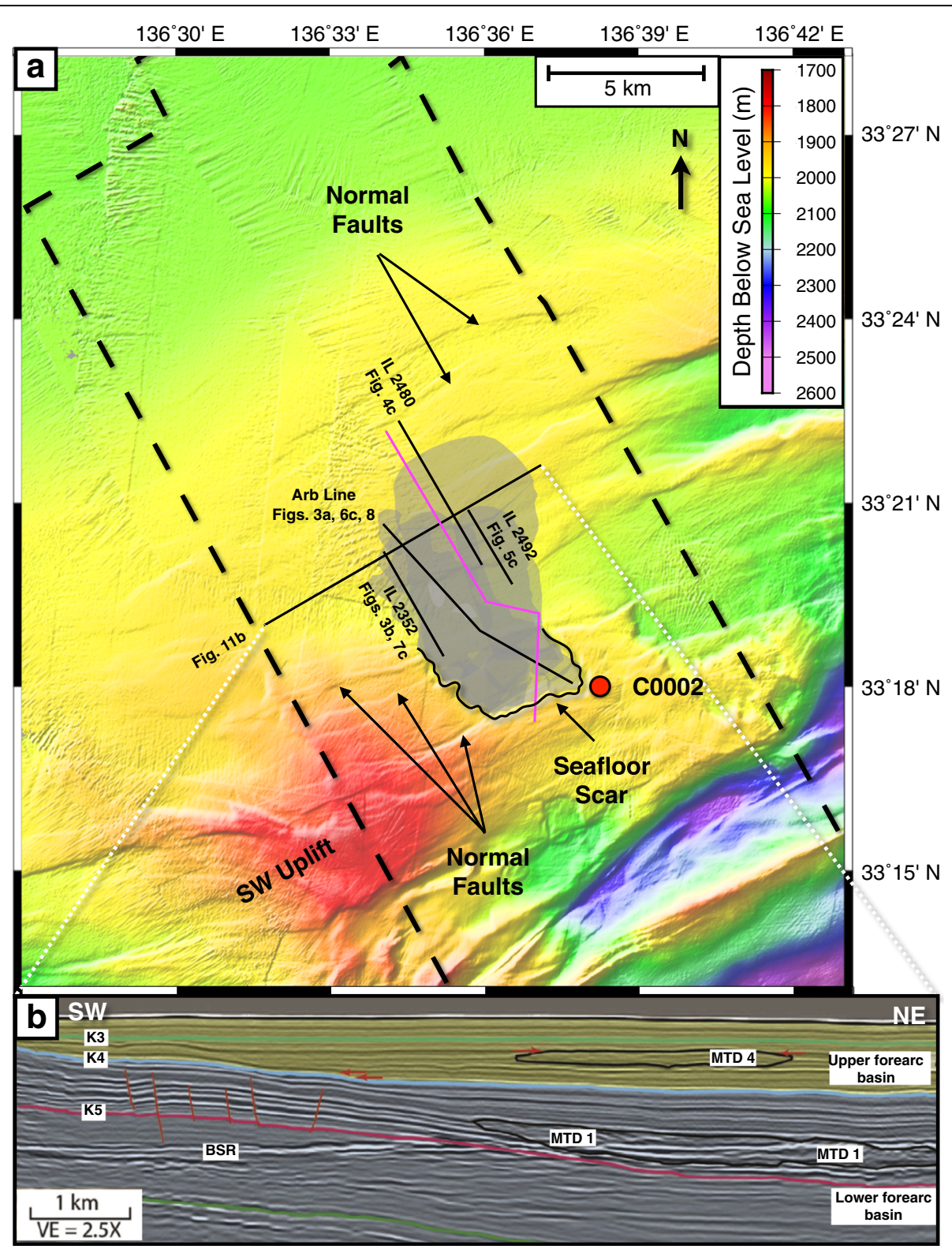

Fig. 11 a High-resolution bathymetry showing SW uplift in relation to the seafloor scar. The gray area represents all the identified MTDs. The purple line indicates the location of the Abstract figure. $\mathbf{b}$ Seismic cross section showing the relative stratigraphic positions of MTD 1 in the lower forearc basin stratigraphy and MTD 4 within the upper forearc basin stratigraphy. K3, K4, and K5 are upper boundaries of the Kumano Basin seismic sequences, based on toplap, downlap, onlap, or angular relations as defined by Gulick et al. (2010). BSR_bottom-simulating reflector. Modified from Moore et al. (2015) 


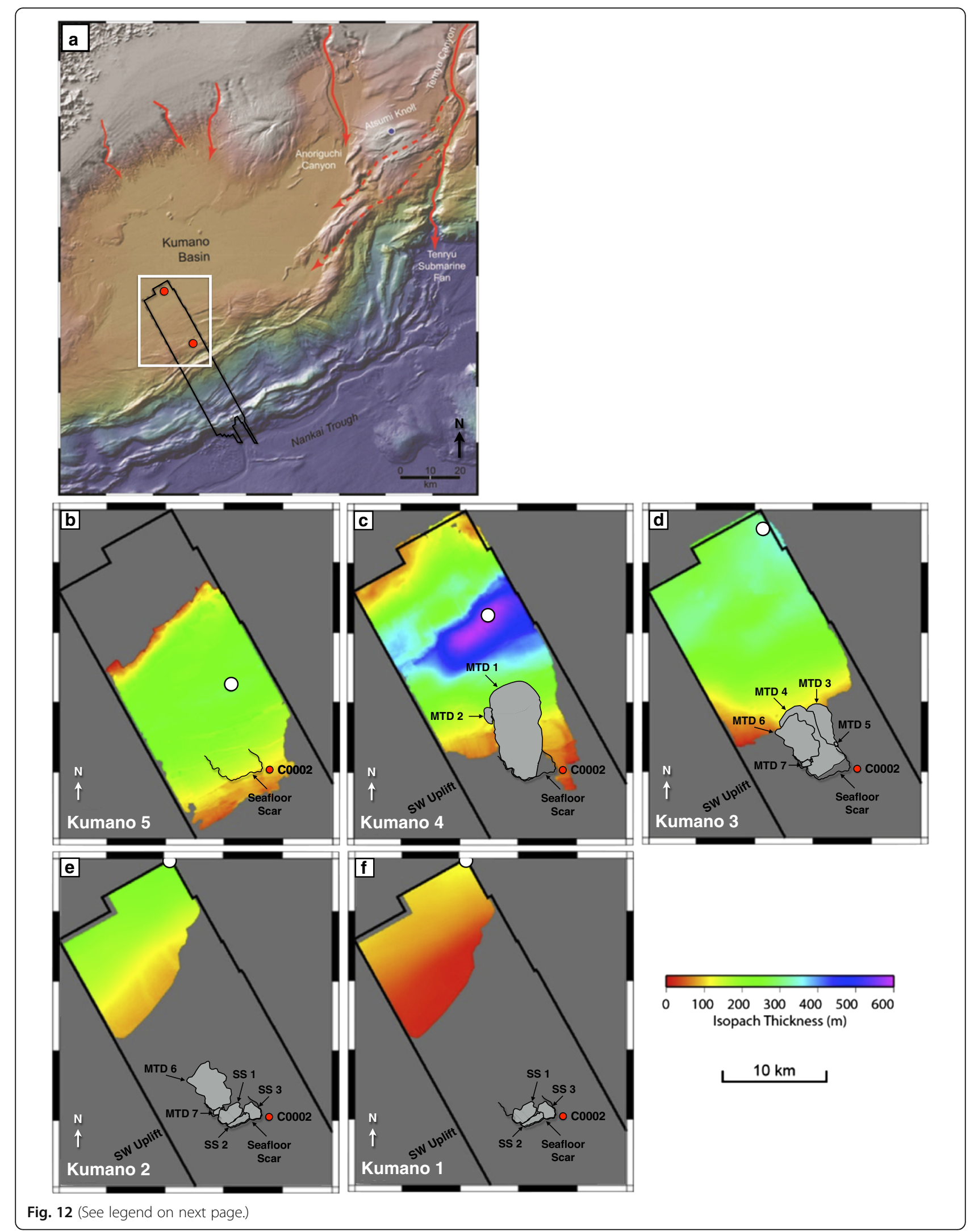


(See figure on previous page.)

Fig. 12 Kumano Basin sedimentation through time. a Map showing the primary sediment inputs to the Kumano Basin. Solid lines show presentday pathways; dashed lines show possible older pathways. Note the bathymetric high to the NE of the 3D seismic volume that prevents modern sedimentation near IODP site C0002. Red dots are IODP drill sites. White box shows the location of isopach maps. b-f Isopach maps of Kumano Basin stratigraphic sequences. Sequence Kumano 1 is the youngest sequence; Kumano 5 is the oldest. White dots show the thickest point of the basin during each isopach interval. Identified MTDs that occur within each sequence are shown for reference. The pattern of deposition changes once the SW uplift appears during the Kumano 4 sequence. Additionally, a lack of sedimentation at the headwalls during Kumano sequences 3-1 helps to explain the reduction in the size of MTDs 5-7 and the surficial MTDs. Because their relative timing cannot be determined from the data, MTDs 6 and 7 are shown in both the Kumano 3 and 2 maps and the surficial MTDs are shown both in the Kumano 2 and Kumano 1 maps (d-f). SS—surficial slide. Modified from Moore et al. (2015)

\section{Conclusions}

A series of nested MTDs is imaged using both 3D seismic data and high-resolution bathymetry in the outer forearc of the Kumano Basin. The nested nature of the observed MTDs and the stratigraphic sequences in which they occur show how sedimentation of the Kumano Basin and tectonic activity of the Nankai accretionary prism affect local mass wasting. We use kinematic indicators from the observed MTDs to reconstruct a prominent seafloor scar. Local slope over-steepening from a rapid uplift SW of the study area possibly coupled with seismic loading caused the initiation of landsliding in the study area $\sim 0.9 \mathrm{Ma}$. Subsequent failures likely occurred because of faulting caused by post-seismic relaxation of the accretionary prism and seismic activity from $0.3-0.44$ Ma to present.

\section{Abbreviations}

3D: Three-dimensional; BSR: Bottom-simulating reflector; CMP: Common midpoint gather; IODP: International Ocean Drilling Program; MBES: Multibeam echosounder; MTD: Mass transport deposit; OOST: Out-of-sequence thrust; PGS: Petroleum Geo-Services; PSDM: Pre-stack depth migration

\section{Acknowledgements}

The new bathymetric compilation was made possible by the hard work of the SO251 Hydroacoustic Group (C. dos Santos Ferreira, K. Bachmann, K. Lange, J. Moernaut). We thank two anonymous reviewers for the comments that greatly improved the manuscript and Paradigm Geophysical and Blue Marble Geographics for making their software available to us. SOEST Contribution \# 10345

\section{Funding}

This work was supported by grants from the National Science Foundation, the US Science Support Program, the German Ministry of Science and Education (BMBF) through funding (grant 03G0251A) of the RV Sonne cruise SO251 that acquired the bathymetric data, and the Austrian Science Foundation (grant P29678-N28 to M.S). The 3D data reprocessing was supported by the Japan Society for the Promotion of Science (JSPS) through a KAKENHI Grant-inAid for Scientific Research S (JP15H05717) and by the Ministry of Education, Culture, Sports, Science, and Technology (MEXT) through management expense grants at the Research and Development Center for Ocean Drilling Science (ODS) and the Center for Deep Earth Exploration (CDEX) of Japan Agency for Marine-Earth Science and Technology (JAMSTEC).

\section{Availability of data and materials}

The 3D seismic reflection and bathymetry data sets are available on request from G. Moore (gmoore@hawaii.edu).

\section{Authors' contributions}

GM proposed the topic and supervised the research. JL carried out the experimental study and analyzed and interpreted the data. MS proposed and directed the bathymetry data acquisition program and collaborated in the construction of the manuscript. All authors read and approved the final manuscript.
Competing interests

The authors declare that they have no competing interest.

\section{Publisher's Note}

Springer Nature remains neutral with regard to jurisdictional claims in published maps and institutional affiliations.

\section{Author details}

'Department of Earth Science, University of Hawai'i, 1680 East-West Rd, Honolulu, HI 96822, USA. ${ }^{2}$ Institute of Geology, University of Innsbruck, Innrain 52f, 6020 Innsbruck, Austria.

Received: 27 March 2018 Accepted: 27 September 2018

Published online: 17 October 2018

\section{References}

Abrahamson NA, Somerville PG (1996) Effects of the hanging wall and footwall on ground motions recorded during the Northridge earthquake. Bull Seismol Soc Am 86:593-S99

Ando M (1975) Source mechanisms and tectonic significance of historical earthquakes along the Nankai Trough, Japan. Tectonophysics 27:119-140

Baba T, Cummins PR, Hori T, Kaneda Y (2006) High precision slip distribution of the 1944 Tonankai earthquake inferred from tsunami waveforms: possible slip on a splay fault. Tectonophysics 426:119-134. https://doi.org/10.1016/j. tecto.2006.02.015

Bardet JP, Synolakis CE, Davies HL, Imamura F, Okal EA (2003) Landslide tsunamis: recent findings and research directions. In: Bardet JP, Imamura F, Synolakis CE, Okal EA, Davies HL (eds) Landslide tsunamis: recent findings and research directions. Pageoph Topical Volumes. Birkhäuser, Basel, pp 1793-1809. https://doi.org/10.1007/978-3-0348-7995-8_1

Bøe R, Hovland M, Instanes A, Rise L, Vasshus S (2000) Submarine slide scars and mass movements in Karmsundetand Skudenedfjorden, southwestern Norway: morphology and evolution. Mar Geol 167:147-165

Bondevik S, Kaland PE, Svendsen JI, Johnsen G, Mangerud J (1997) The Storegga tsunami along the Norwegian coast, its age and runup. Boreas 26:29-53

Bull S, Cartwright J, Huuse M (2009) A review of kinematic indicators from masstransport complexes using 3D seismic data. Mar Pet Geol 26(7):1132-1151. https://doi.org/10.1016/j.marpetgeo.2008.09.011

Caress DW, Chayes DN (1996) Improved processing of Hydrosweep DS multibeam data on the RN Maurice Ewing. Mar Geophys Res 18:631-650

DeVore JR, Sawyer DE (2016) Shear strength of Siliciclastic sediments from passive and active margins (0-100 $\mathrm{m}$ below seafloor): insights into seismic strengthening. In: Lamarche $\mathrm{G}$ et al (eds) Submarine mass movements and their consequences. Advances in natural and technological hazards research, vol 41. Springer, Cham, pp 173-180. https://doi.org/10.1007/978-3-319-20979-1_17

Farrell SG (1984) A dislocation model applied to slump structures, Ainsa Basin, South Central Pyrenees. J Struct Geol 6:727-736

Fitch TJ (1972) Plate convergence, transcurrent faults, and internal deformation adjacent to Southeast Asia and Western Pacific. J Geophys Res (23):4432-4460

Frey Martinez J, Cartwright J, Hall B (2005) 3D seismic interpretation of slump complexes: examples from the continental margin of Israel. Basin Res 17:83-108

Frey Martinez J, Cartwright J, James D (2006) Frontally confined versus frontally emergent submarine landslides: a 3D seismic characterisation. Mar Pet Geol 23:585-604

Gafeira J, Bulat J, Evan D (2007) The southern flank of the Storegga Slide: imaging and geomorphological analyses using 3D seismic. In: Lykousis V, 
Sakellariou D, Locat J (eds) Submarine mass movements and their consequences. Springer, Dordrecht, pp 57-66

Gee MJR, Gawthorpe RL, Friedmann JS (2005) Giant striations at the base of a submarine landslide. Mar Geol 214:287-294. https://doi.org/10.1016/j.margeo.2004.09.003

Gee MJR, Gawthorpe RL, Friedmann SJ (2006) Triggering and evolution of a giant landslide, offshore Angola revealed by 3D seismic stratigraphy and geomorphology. J Sediment Res 76:9-19

Gulick SPS, Bangs NLB, Moore GF, Ashi J, Martin KM, Sawyer DS, Tobin HJ, Kuramoto S, Taira A (2010) Rapid forearc basin uplift and megasplay fault development from 3D seismic images of Nankai Margin off Kii Peninsula, Japan. Earth Planet Sci Lett 300(1-2):55-62. https://doi.org/10.1016/j.epsl.2010.09.034

Ikari MJ, Strasser M, Saffer DM, Kopf AJ (2011) Submarine landslide potential near the megasplay fault at the Nankai subduction zone. Earth Planet Sci Lett 312: 453-462 https://doi.org/10.1016/j.epsl.2011.10.024

Kimura G, Kitamura Y, Hashimoto Y, Yamaguchi A, Shibata T, Ujiie K, Sy O (2007) Transition of accretionary wedge structures around the up-dip limit of the seismogenic subduction zone. Earth Planet Sci Lett 255:471-484. https://doi. org/10.1016/j.epsl.2007.01.005

Kimura G, Moore GF, Strasser M, Screaton E, Curewitz D, Streiff C, Tobin H (2011) Spatial and temporal evolution of the megasplay fault in the Nankai Trough. Geochemistry Geophysics Geosystems 12. https://doi.org/10.1029/ 2010gc003335

Kinoshita M, Tobin H, Ashi J, Kimura G, Lallemant S, Screaton EJ, Curewitz D, Masago $H$, Moe KT, expedition scientists (2009) Proc. IODP, 314/315/316. https://doi.org/10.2204/iodp.proc.314315316.2009

Kremer K, Usman MO, Satoguchi Y, Nagahashi Y, Vadakkepuliyambatta S, Panieri G, Strasser M (2017) Possible climate preconditioning on submarine landslides along a convergent margin, Nankai Trough (NE Pacific). Prog Earth Planet Sci 4:20. https://doi.org/10.1186/s40645-017-0134-9

Lackey JK, Moore GF, Strasser M, Kopf A, Ferreira CS (2018) Spatial and temporal cross-cutting relationships between fault structures and slope failures along the outer Kumano Basin and Nankai accretionary wedge, southwest Japan. In: Submarine Mass Movements and their Consequences. Advances in Natural and Technological Hazards Research in press

Lastras G, Canals M, Hughes-Clarke JE, Moreno A, De Batist M, Masson DG, Cochonat $P$ (2002) Seafloor imagery from the BIG'95 debris flow, western Mediterranean. Geology 30:871-874

Lee HJ (2009) Timing of occurrence of large submarine landslides on the Atlantic Ocean margin. Mar Geol 264:53-64

Lee HJ, Locat J, Boulanger E, Konrad JM (2004) Seismic strengthening, a conditioning factor influencing submarine lanslide development. Paper presented at the 57th Canadian Geotechnical Conference; 5th Joint CGS/ IAH-CNC Conference, Quebec City, Quebec, pp 24-27

Locat J, Lee H, Kayen R, Israel K, Savoie M-C, Boulanger E (2002) Shear strength development with burial in Eel River margin slope sediments. Mar Georesour Geotechnol 20(2):111-135. https://doi.org/10.1080/03608860290051_831

Lucente CC, Pini GA (2003) Anatomy and emplacement mechanism of a large submarine slide within a Miocene foredeep in the northern Apennines, Italy: a field perspective. Am J Sci 303:565-602

Martinsen OJ (1994) Mass movements. In: Maltman A (ed) The geological deformation of sediments. Chapman and Hall, London, pp 127-165

Masson DG, Hugget QJ, Brunsden D (1993) The surface texture of the Saharan debris flow deposit and some speculation on submarine debris flow processes. Sedimentology 40:583-598

Matheus S, Sobiesiak G, Alsop I, Kneller B, Milana JP (2017) Sub-seismic scale folding and thrusting within an exposed mass transport deposit: a case study from NW Argentina. J Struct Geol 96:176-191. https://doi.org/10.1016/j. jsg.2017.01.006

Miyakawa A, Saito S, Yamada Y, Tomaru H, Kinoshita M, Tsuji T (2014) Gas hydrate saturation at site C0002, IODP expeditions 314 and 315, in the Kumano Basin, Nankai Trough. Island Arc 23:142-156

Moore GF, Boston BB, Sacks AF, Saffer DM (2013) Analysis of normal fault populations in the Kumano Forearc Basin, Nankai Trough, Japan: 1. Multiple orientations and generations of faults from 3-D coherency mapping. Geochem Geophys Geosyst 14:1989-2002. https://doi.org/10.1002/ggge.20119

Moore GF, Boston BB, Strasser M, Underwood MB, Ratliff RA (2015) Evolution of tectonosedimentary systems in the Kumano Basin, Nankai Trough forearc. Mar Petrol Geol 67:604-616. https://doi.org/10.1016/j.marpetgeo.2015.05.032

Moore GF, Kanagawa K, Strasser M, Dugan B, Maeda L, Toczko S, Exp 338 Sci. Party (2014) IODP Expedition 338: NanTroSEIZE Stage 3: NanTroSEIZE plate boundary deep riser 2. Sci Dril 17:1-12. https://doi.org/10.5194/sd-17-1-2014
Moore GF, Park JO, Bangs NL, Gulick SP, Tobin HJ, Nakamura Y, Saito S, Tsuji T, Yoro T, Tanaka H, Uraki S, Kido Y, Sanada Y, Kuramoto S, Taira A (2009) Structural and seismic stratigraphic framework of the NanTroSEIZE Stage 1 transect. Proc. IODP, 314/315/316, pp 1-46. https://doi.org/10.2204/iodp.proc. 314315316.102.2009

Moore GF, Strasser M (2016) Large mass transport deposits in Kumano Basin, Nankai Trough, Japan. In: Lamarche $\mathrm{G}$ et al (eds) Submarine mass movements and their consequences advances in natural and technological hazards research, vol 41: 371-379. Springer, Cham. https://doi.org/10.1007/978-3-319-20979-1_37

Moore JG, Clague DA, Holcomb RT, Lipman PW, Normark WR, Torresan ME (1989) Prodigious submarine landslides on the Hawaiian ridge. J Geophys Res Solid Earth Planets 94:17465-17484

Plafker G (1972) Alaskan earthquake of 1964 and Chilean earthquake of 1960: implications for arc tectonics. J Geophys Res 77:901-925

Prior DB, Bornhold BD, Johns MW (1984) Depositional characteristics of a submarine debris flow. J Geol 92:707-727

Prior DB, Coleman JM (1978) Disintegrating retrogressive landslides on very-lowangle subaqueous slopes, Mississippi Delta. Mar Geotechnol 3(1):37-60

Ruff L, Kanamori H (1980) Seismicity and the subduction process. Phys Earth Planet Inter 23(3):40-252

Sacks AF, Saffer DM, Fisher DM (2013) Analysis of normal fault populations in the Kumano Forearc Basin, Nankai Trough, Japan: 2. Principal axes of stress and strain from inverson of fault orientations. Geochem Geophys Geosyst 14:1973-1988

Satake K (2012) Tsunamis generated by submarine landslides. In: Yamada Y (ed) Submarine mass movements and their consequences. Advances in natural and technological hazards research, vol 31. Springer, Dordrecht/Heidelberg/London/ New York, pp 475-484. https://doi.org/10.1007/978-94-007-2162-3_42

Seno T (1989) Philippine Sea Plate kinematics. Mod Geol 14:87-97

Shiraishi K, Moore GF, Yamada Y, Kinoshita M, Kimura G (2018) Seismogenic zone structures revealed by improved 3D seismic images in the Nankai Trough off Kumano. Prog Earth Planet Sci

Strasser M, Dugan B, Kanagawa K, Moore GF, Toczko S, Maeda L, Expedition 338 Scientists (2014) Proc. IODP, 338: Yokohama (Integrated Ocean Drilling Program). https://doi.org/10.2204/iodp.proc.338.2014

Strasser M, Henry P, Kanamatsu T, Thu MK, Moore GF and scientists (2012) Scientific drilling of mass-transport deposits in the Nankai accretionary wedge: first results from IODP Exp 333. In: Yamada Y, et al (eds) Submarine mass movements and their consequences. Advances in natural and technological hazards research, vol 31, pp671-681. Springer, Dordrecht. doi: https://doi.org/10.1007/978-94-007-2162-3-60

Strasser M, Kopf A, Abegg FW, Asada M, Bachmann AK, Cuno P, Dos Santos Ferreira C, Fleischmann T, Fujiwara T, Hatakeyama E, Heesemann BR, Hillman JIT, Hoehne M, Huusmann H, Ikari M, Ikehara K, Jaeger FD, Kanamatsu T, Kang M, Kaul NE, Kioka A, Koelling M, Lange K, Luebben N, Matthiessen T, Mchugh CM, Meier A, Menapace W, Mochizuki K, Moernaut J, et al (2017) REPORT AND PRELIMINARY RESULTS OF RN SONNE CRUISE SO251: Extreme events Archived in the GEological Record of Japan's Subduction margins (EAGER-Japan). Berichte, MARUM - Zentrum für Marine Umweltwissenschaften, Fachbereich Geowissenschaften, Universität Bremen

Strasser M, Moore G, Kimura G, Kopf A, Underwood M, Guo J, Screaton E (2011) Slumping and mass-transport deposition in the Nankai forearc: evidence from IODP drilling and 3-D reflection seismic data. Geochem Geophys Geosyst 12:Q0AD13. https://doi.org/10.1029/2010GC003431

Strasser M, Moore GF, Kimura G, Kitamura Y, Kopf AJ, Lallemant S, Park JO, Screaton EJ, Su X, Underwood MB, Zhao X (2009) Origin and evolution of a splay fault in the Nankai accretionary wedge. Nat Geosci 2:648-652

Taira A (2001) Tectonic evolution of the Japanese island arc system. Annu Rev Earth Planet Sci 29:109-134

Tanioka Y, Satake K (2001) Coseismic slip distribution of the 1946 Nankai earthquake and aseismic slips caused by the earthquake. Earth, Planets and Space 53:235-241

Underwood MB, Moore GF (2012) Evolution of sedimentary environments in the subduction zone of southwest Japan: recent results from the NanTroSEIZE Kumano transect. In: Busby CJ, Azor AP (eds) Tectonics of sedimentary basins: recent advances. Wiley-Blackwell, New York, pp 310-326

Urlaub M, Talling PJ, Masson DG (2013) Timing and frequency of large submarine landslides: implications for understanding triggers and future geohazard. Quat Sci Rev 72(0):63-82. https://doi.org/10.1016/j.quascirev. 2013.04.020

Ward SN, Day S (2002) Suboceanic landslides. 2002 Yearbook of science and technology, pp 249-352 